\title{
The Political Aesthetics of Middle Class Housing in (not so) Neoliberal Mozambique
}

\author{
Jason Sumich, University of Essex \\ Morten Nielsen, National University of Denamrk
}

\begin{abstract}
This article explores the social and material repercussions of middle class aspirations in a system that is still infused by socialist aesthetics in Maputo, Mozambique. We argue the activation of "middle classness" reproduces ingrained inequalities and boundaries. This is demonstrated through two ethnographic case studies of urban housing, long central to imaginaries of prosperity: First, fearing downward mobility, members of the upper middle class seek to embody a liberal ideology of 'autonomy', while simultaneously being dependent on state structures. Second, members of the lower middle class attempt to create enclaves to experiment with forms of privatization normally only accessible to a privileged elite. Through this examination of the ways in which a spectrum of privileged urbanites attempts to secure their position in the face of a precarious future, the article outlines middle classness under contemporary capitalist conditions and how this is shaped by the legacies of the past.
\end{abstract}

Keywords: middle class, urban housing, social stratification, political aesthetic, ideology, Maputo.

\section{Introduction}

In recent years, the supposed 'rise' of a middle class in Africa has aroused significant interest among academics and development practitioners alike (Lentz 2015; Lopes 2015; Melber 2016; Ncube and Shimeles 2013; Southhall 2016; Spronk 2012). This interest is spurred on by breathless reports from various agencies, such as the African Development Bank, which claim that over 300 million people on the continent are already members of the middle class as they have a purchasing power of between US $\$ 2$ and US\$20 a day (Mubila et al. 2011) - irrespective of the cost of living. Such claims about the latent economic capacities of one of the world's poorest regions have not gone unnoticed by a mixed bag of analysts, fuelling speculation about Africa's bright future. Building on the implicit but powerful ideological subtext in the discourses of 
institutions like the African Development Bank, the International Monetary Fund (IMF) and the World Bank (see Kalb 2014), these analysts suggest that the growing African middle class will ultimately become agents of transformation, producing the autonomous, responsible, governable and entrepreneurial liberal subjects who will lift the continent from decades of authoritarianism, poverty and despair (for wider examples see Heiman, Freeman and Liechty 2012, Kipnis 2007).

In the following, however, we wish to cast a critical perspective on the alleged triumph of the middle, as it were, by focusing on particular ways in which discourses of "middle classness" in Mozambique are intertwined with broader processes of societal transformation. Rather than serving as a catalyst for securing a robust democratic societal integration, we argue that the activation of "middle classness" maps out and reproduce ingrained divides and boundaries between already existing sociogeographical positions and statuses (cf. Lentz 2015). We build on insights from a growing body of work which emphasises how "middle classness" is performed under the constraints and opportunities unleashed by sweeping economic change (Buire 2017, Gastrow 2017, Mercer 2014, Pow 2009). Expanding on these crucial insights, we explore how middle classness is employed by differently positioned actors as a fractured political aesthetics that has been key to scaffolding the social and political landscape of Mozambique since independence in 1975. In this regard, the activation of "middle classness" provides a potent social and political framework for re-introducing or re-activating utopian, if dormant, projects of social engineering albeit in constantly mutating forms.

An emphasis on the middle class as driver for social and economic chance does not by itself indicate that there is a phenomenon 'out there' that reflects the characteristics, which are seemingly captured by the concept. We will therefore refrain from providing a strict definition on who does or does not belongs to the middle class, but rather explore the ways in which social actors of varying levels of privilege and power employ ideas and strategies associated with the notion of the middle classness. We consider middle classness as referring to the multiple and overlapping social, political and economic effects of activating 'middle class' as a key driver of societal change in local urban environments. Whereas the middle class as a social category might never be fully formed, it does stencil into the urban fabric new and often unstable relationships of obligation and dependences.

Housing provides the material focal point for local discourses of middle classness and forms of privilege, which we shall discuss below. For the Portuguese colonizers as well as for the ruling Frelimo (Mozambique Liberation Front) government (in both its socialist and its neo-liberal renderings), housing has been central to urban political and economic reforms (Nunes Silva 2015; Saul 1985). It did not only establish one's status for the world to see, it was also a vehicle through which both the state apparatus and social actors of varying levels of privilege attempted, in a fraught, often conflictual, coercive and hideously unequal manner, to constitute the social and aesthetic boundaries of what urban citizenship might mean. As noted by Dalakoglou 
(2010), housing is not simply a physical structure; it is also a way of creating in a concrete form a set of cultural logics and social relations. Hence, in the case of Maputo, the nation's worn-out capital, housing continues to function as an ideological vehicle for hardening social differentiations in the very materiality of the city (Roque, Mucavele et. al. 2016).

In her work on Dakar, Melly argues that seemingly abstract shifts in policy, regulation and political economy are experienced in profoundly personal and embodied ways by the city's residents (2017: 19). Although Maputo has a very different history, like Dakar, transformations in the urban political economy and housing policy are not simply felt in the context of economic livelihood strategies and forms of governance but affect also urban subjectivities in multiple and often inconsistent ways. If in Dakar, processes of structural adjustment and liberalisation have transformed the symbol of popular urban success from the salaried civil servant to the migrant, in Maputo this has been embodied by the transformation from the socialist vision of the homem novo (New Man) to the capitalist dream of the middle class citizen. Significantly, in Maputo, housing serves as an outward manifestation of what kind of person the occupant is, what their aspirations, desires and hopes for the future are (Nielsen 2016). These personal and shared hopes and ideas continue to be shaped by the legacies of the past.

As we shall show, these legacies are central to what Ranciére called a 'the politics of aesthetics' (2004), that is, the organisation of what is sensible and what is unthinkable. For Ranciére, aesthetics constitutes 'a system of a priori forms determining what presents itself to sense experience. It is a delimitation of spaces and time, of the visible and the invisible, of speech and noise, that simultaneously determines the place and the stakes of politics as a form of experience' (2004:63). With a now famous phrase, Ranciére describes aesthetics as the 'distribution of the sensible' (partage $d u$ sensible), which refers both to the conditions of sharing that constitute a particular community and, at the same time, to the sources of dissensus, the contestation and differentiation of that very community (Rancière 2010; see also Panagia 2010). The distribution of the sensible precedes political involvement by determining what is socially visible, as it were, by creating a correspondence between perception and meaning. According to Ranciére, there is therefore always a particular 'aesthetics' at the heart of political processes (2004): In all socio-political arrangements, words, images and ideas are in constant circulation and these may at any moment be configured so as to give rise to dissent and strife.

To a certain extent, aesthetic practices operate through acts of inclusion and exclusion within a common domain. They define and delimit a perceptible field precisely by specifying what can and cannot be seen within it. But this also indicates that a given distribution of the sensible might be configured otherwise. Ranciére reminds us that for any distribution to occur, certain criteria have to be in place that organize the 'order of the distribution of bodies into functions corresponding to their 'nature' and places corresponding to their functions' (1998:101), such as the socialist ideological imagery of proper moral conduct in the city. Aesthetic practices, then, 
become political by reconfiguring the organization of the visible and the invisible and introducing new subject positions, images and ideas into the field of perception (Ranciére 2004:63).

In Maputo, then, members of different urban factions, who associate themselves with ideas of the middle class both repudiate and are trapped by a defunct ideological project, which nevertheless conjures an increasingly fleeting memory of a nationalist utopia that collapsed long ago. Based on long-term ethnographic research carried out by both authors in Maputo, we explore the relationship of two groups of social actors who possess significant, if unequal, levels of social privilege enact the discourse of middle classness as a way of activating a dominant, if dilapidated political aesthetics. Inspired by Ranciére, we will subsequently argue that the result is the reproduction of a dual political aesthetics: Middle classness offers a kind of immediate political identification at a certain distance from the ideological mire in which the governing Frelimo party seems to have positioned itself. At the same time, however, the undercurrent of this political aesthetics is one that constantly pushes these urbanites back into the orbit of the Frelimo party and reactivates elements of the proper moral conduct for an urbanite. The result is the almost paradoxical consolidation of a social and political organisation, which very few urbanites want to preserve.

The first configuration that we are examining consists of urbanites who are not part of the national political elite themselves but have occupied privileged societal positions since the early independence period and, in some cases, even since the colonial era (see also Pow 2009 for an account of the flexibility of the label middle class in China). Many would be popularly considered as members of an elite due to their professions and salaries, but perhaps more importantly for a variety of social and political factors. This includes individuals' closeness to the powerful, in a political system jokingly referred to as a ditadura de apelidos (dictatorship of surnames, referring to the party 'aristocracy', who monopolize power and, since the fall of socialism, economic opportunities). The drive to be associated with a national middle class here basically serves as a way to legitimise privilege, while simultaneously drawing a distinction between themselves and what they view as a corrupt and increasingly malignant elite.

The second configuration focuses on an experimental appropriation of 'middleclassness' by urbanites whose socio-economic status does not seem to afford such privileges. In general, these urbanites work at the lower levels of the state and municipal apparatus and are both socially and, indeed, materially, at considerable distance from society's main power holders. Throughout Maputo, recently built compounds and 'gated communities' offer new opportunities for increased privacy and security to a growing number of those urbanites, who want to escape from the disorder, weak infrastructure and paltry social services of the city centre. While the majority of these urban enclaves are built for the elite, several compounds are probably best considered as social housing projects intended for officials with limited financial capacities. To many residents living in these compounds a semi-detached house surrounded by peers with 
relatively similar economic and social background is not an ideal situation. Young state officials hope to eventually leap beyond the constraints of the middle class and enter the hallowed halls of the party aristocracy, whose status and privileges presumably give them complete freedom and autonomy. Here, the activation and usage of 'middleclassness' is nothing but a steppingstone that allows for an initial experimentation with forms of privatization that are otherwise the privilege only of the wealthy elite. As a manifestation of a Ranciérian double political aesthetics, these sections of the urban population seem to material embody a social ideal, which is also nearly impossible to achieve.

Hence, in both instances we find urbanites who are alienated from the state but who, as we shall see in the following, through their respective actions and practices, come to reproduce a crumbling social order, whose symbolic tropes have survived into the present day despite its ideological promises being long broken.

\section{A fractured political cosmology: The making of socialism in Mozambique}

In Lourenço Marques, as the capital was known in the colonial period, housing was strictly segregated by race and class. From the well-appointed villas and modernist apartment buildings reserved for the settler elite in the cidade de cimento (cement city) all the way to the ramshackle huts on the outskirts of the cidade de caniço (reed city), housing was emblematic of a colonial system of stratification. Indeed, both the forms of housing - its aesthetics, location and uses - and the moral qualities ascribed to domestic life were central to the colonial state's extremely limited 'civilizing' project of assimilação (assimilation). For this relatively privileged, if miniscule fraction of the population that achieved the status of assimilados and a house made of wood and zinc as opposed to commonly used reed constructions was not only a symbol of success, this form of dwelling was a legal requirement for the status of assimilado (Morton 2019: 37). A house made of wood and zinc symbolised an entry into a form of urban citizenship which allowed preferential access to education, employment and freedom from forced labour, and the ability to reside in a part of town that was relatively wellserviced and luxurious in comparison to that of the Indigenas (indigenous or natives).

Much of Frelimo's political leadership was drawn from embittered, former assimilados who agreed with the colonizers that Mozambique's population was profoundly backwards, but who nevertheless advocated a dramatically different solution. The kind of socialism which they championed combined elements of their assimilado scepticism towards so-called 'obscurantist' traditional social structures and institutions with broader, leftist ideological currents (See Cruz e Silva 2001 for an illuminating discussion on the role of the Protestant Church in shaping Frelimo's ideology, a detailed discussion of which is beyond the scope of this paper). The result was a nationalist version of Marxist-Leninism carrying a new 'civilizing' project that was more ambitious and wide-ranging than the wildest dreams of the colonizers. Its goals, utopian in nature and authoritarian in practice, were to abolish patriarchy, gerontocracy, selfish individualism, tribalism, rural feudalism, superstition, 
obscurantism and other 'backwards' cultural practices as part of a modernizing mission (Vieira 1977). In their place, a homogenized, 'rational' new man who selflessly strived for the collective good would emerge (ibid).

After fighting an 11-year liberation struggle, Frelimo proclaimed independence in 1975 and set out to implement its programme of social engineering to create a new national subject from the supposedly backward, fragmented population. A prime example in Maputo was the decree on the nationalization of the abandoned housing stock in the formerly colonial centre of town and the distribution of flats to cadres and urbanites who had previously resided in under-served bairros (Jenkins 1998, Pinsky 1982, Nielsen 2020 forthcoming). The stated goals of this decree were to abolish the injustices of colonialism and build a national form of poder popular (peoples' power) that would usher in a socialist society. However, the egalitarian presumptions of the regime concerning urban areas were predicated on a very particular understanding of what it meant to be an urban citizen. (see also Buire 2017 and Gastrow 2017). Morton argues, "To enjoy the privileges of the City of Cement, one had to already have certain privileges. Elites may have been muscling in to obtain the best properties, but the built inheritance itself also encouraged social segregation" (2019: 165). Not only was living in the city centre expensive in many ways not covered by subsidised rents, including costs for electricity and water, but the built environment was suitable for only certain kinds of economic activities. The apartment blocks of the city centre had no yards where people could open a shop or kiosk, or brew beer, activities that had long been economic mainstays for much of the urban population. "By 1979 most of the cement city was occupied, but not many family heads were working class, it was mainly the service sector and the bureaucracy" (ibid: 165). While Frelimo attempted to open the cement city to all, it soon became a preserve of a relatively privileged nomenklatura, and once again modern urban citizenship became the preserve of the chosen few.

Shortly after independence, the white minority regimes of Rhodesia and then apartheid South Africa formed and supported an internal rebel group, Renamo (Mozambican National Resistance), to destabilize their left-wing neighbour. Renamo built on dormant internal discontent with Frelimo's social engineering, plunging the country into civil war (Dinerman 2006). The violence was worst in the rural areas, leading to a massive influx of refugees to the relative safety of the cities. During this period, Maputo's outlying bairros expanded at an incredible rate, straining the capacity of the city's authorities as the country slid towards economic meltdown.

Maputo's role in shaping the selfless new national citizen began to falter as the state struggled to sustain the population, while smuggling, pilfering, black marketeering and various other forms of what was labelled 'economic sabotage' became necessary to ensure survival (Buur 2010). The socialist icon and first president, Samora Machel, signalled a change of direction in 1983 and various market mechanisms were tentatively reintroduced, a pace that accelerated dramatically after Machel's death in 1986.

Reforms came with increased aid from the 'west', but life for urbanites became even more precarious as the currency was devalued, salaries were cut and corruption, once 
relatively rare, flourished. By the late 1980s, the previous socialist dreams remained as slogans, but otherwise had little relationship to people's daily lives. Despite its revolutionary promises, however, Frelimo's socialist-inspired dreams of a brave new world collapsed irrevocably at the end of the civil war. Crucially for the present discussion, however, the underlying discourse of radical societal transformation survived, albeit in a reconfigured and less politically charged form (Nielsen 2014; 2017, Sumich 2016, 2018). For, as we shall shortly see, if the nation could not be made autonomous and modern, privileged social subjects still could be.

\section{Middle-class articulations and the party-state machine (1990 to present)}

Around 1990, while the civil war between Frelimo and Renamo lurched towards its conclusion, many of those urbanites who had once been the epitome of the socialist 'new man' became enamoured with the beguiling opportunities of the market (Pitcher $2002,2006)$. The embrace of capitalism would soon transform urban life and social relations as the government moved to privatize the housing stock, for symbolic prices, opening the door for home ownership and even the possibility of becoming a landlord. Senhor Marques, a former minister, explained the process as follows:

We had to get the government out of the housing market, the stock was rapidly deteriorating and the state simply could not take care of it. We thought that we had to help the people and so we did... it was an ad-hoc move without long-term planning. Initially, with housing privatization the idea was that one was only able to buy the house that they were renting, the trading came later. However, there were many ways around this as people started registering houses in the names of their wives or children. They would buy houses, still cheap, from a person whose salary was so small that they could not pay for it, or through the trading.

The growth of a thriving real estate market, while seemingly unintended, was in many ways the epitome of Frelimo's version of capitalism, as it created a vital commodity, but where the market was characterized by confusion and ambiguity, allowing the powerful significant leverage (Jenkins 2001, Negrão 2004). The privatization of housing also allowed actors to control an asset that was distinct from political office, but where the access to such a commodity was, to varying degrees, dependent on political connections and luck. One particularly widespread informal system was known as 'vender a chave' (selling keys). This is when you find a person who is renting a government house, but does not have the money to buy it, although they are very cheap; one trades the house they have for the rented one and then buys it from the government.

Under successive structural adjustment programmes, which began in the mid1980s, industries closed and salaries in the nation's largest employer, the state bureaucracy, were frozen. In this unstable situation, members of the party aristocracy used their political base to accrue economic power (Castel-Branco, et al. 2001; Pitcher, 
2002). As is sadly common throughout Africa, these programmes did not usher in a new era of prosperity, but rather solidified and intensified existing hierarchies and inequalities (Melly 2017: 36). Nor did economic liberalization free the nation from the 'dead hand of the state'; in fact, Frelimo soon became a major economic actor through partnerships with multinational actors in its own right, keeping important segments of the economy under its control (Pitcher, 2002). While the elite was able to expand from its political base and become a powerful economic player, most urban Mozambicans faced deepening and persistent precariousness, especially with the massive job losses that accompanied privatization.

In such a situation, 'the great housing giveaway' was probably among the more economically inclusive aspects of capitalism in Maputo, even if it still primarily benefitted a relatively narrow, politically connected segment of the population. Through the acquisition of multiple houses, one could amass capital, especially by charging foreigners and NGOs staggeringly high rents. Sumich was told of duplexes in Maputo, where Mozambicans would pay US\$3 a month in rent to the state while NGOs, considered as private agents, would pay US $\$ 10,000$. Although this story may be apocryphal, it does illustrate the sense of disjunction and possibility that characterized the time. In many cases, rents were often invested in further education, enabling former members of the nomenklatura to obtain often rotating employment with the state, foreign NGOs and newly privatized businesses. This group of privileged post-socialist urbanites, was enterprising, at least in relation to the narrow channels that were open to it, but remained largely dependent on the party-state (see Soares de Oliveira 2015 for a discussion of similar processes in Angola). The city centre, however, provided a finite resource for class consolidation. Much of the property was soon snapped up and the price of housing began to rise rapidly. In 2013, prices for a three-bedroom house in the affluent, central neighbourhoods of Maputo were close to US\$1,000,000 putting it out of reach for all but the very top of the social hierarchy.

For those who are privileged but cannot afford a house in the city centre and, unlike their parents, will not benefit from privatization, there is an archipelago of gated communities springing up throughout Maputo, Matola and neighbouring regions (Costa Forthcoming; Morange, Folio et al. 2012; Nielsen \& Jenkins 2019 (In press); Quembo 2009). These create some opportunities for achieving the middle-class domestic ideal but are based on deepening forms of exclusion. As one of Sumich's friends, who lives in a gated community, pointed out ironically: 'Yes, they built these with Chinese labour, even though we are surrounded with the shacks of the unemployed'. The everincreasing gated communities are carefully guarded from the wider population, but unlike the case with the mass distribution of the socialist period, only a few will ever reach them (cf. Paasche and Sidaway 2010).

It may be argued that those who claim the mantle of 'middle classness' in Mozambique and elsewhere on the African continent are largely an outgrowth of the state that created them (Sumich 2016, 2018 see also Southall 2016 for a wider discussion). Land in Mozambique is still the property of the state, although citizens can 
own surface rights (Andersen et al 2015a, McAuslan 2013). The lack of a clear overall legal framework concerning land rights and the seeming disinterest in creating one gives state officials significant leeway and bolsters the need for political connections. To this day, the state does not have a reliable register of property rights and has actively impeded any efforts to create one (Andersen, et al 2015a). ${ }^{1}$ The hunger for land is seemingly endless (Hanlon 2011; see also FIAN International Secretariat 2010; Wise 2015): there is a scramble to take plots wherever they are available, even if far outside current municipal boundaries. In these instances, entrepreneurial urbanites get what they can and then wait for the city to arrive, which is expected to raise the value of the property. Instead of creating an independent middle class, though, the strategy of privatizing urban housing paradoxically tends to reinforce dependence on the state as the political process concerning land rights in urban areas is both top down and seemingly deliberately confusing (Jenkins 2013, Swedesurvey 1999). The lack of administrative coordination and control is what allows some local officials, such as the secretario do bairro (neighbourhood secretary), wide scope to conduct informal land deals and approve land rights according to their own personal agendas (Andersen et al. 2015b, Negrão 2004). As local officials frequently sell the same plot of land to multiple people simultaneously, many urbanites consider it more expedient to simply stake one's claim to land by building a small thatch or cement house based on the (often quite accurate) assumption that formal authorities consider the materiality of an object more valuable than a dubious paper title. With a dwindling supply of land near the capital, though, the post-socialist system of stratification has become etched in the landscape itself. Driving through the outskirts of Maputo one frequently sees plots of land encircled by concrete walls with a demolished thatch or cement house in the centre. In many instances, this is the result of some powerful or better-connected individual having taken over - often through informal means - the former owner's claim to the land by simply levelling their house and building a more permanent, protective structure in its place.

There is no doubt that Maputo's physical landscape has been rapidly changing during the last few decades, not least as a result of the growing number of construction projects initiated either by local entrepreneurs or as public-private construction projects with foreign financial investors. In 2012, there were thus more than 80 gated compounds (condomínios) in and around the city centre (Costa n.d.), most of which were built to accommodate the national political elite and upper middle class as well as a still-growing number of foreign investors and 'expats'. It is particularly near the picturesque coastline towards the Maputo Bay that many of the new middle class condominiums have been built. As one descends from the city centre and drives northward out of the city along the Avenida Marginal that runs parallel to the coastline, the changing physical environment is immediately visible. Only within the first kilometre, there are twelve condominiums in the area bordering the road as well as a

\footnotetext{
${ }^{1}$ The Frelimo mayor Eneas Comiche was removed by the national government, in part for his efforts to introduce a cadaster, although he has been reinstated in February of 2019.
} 
couple of newly built shopping malls, which will presumably serve the needs of the financially active consumers who are now living in the vicinity. But it is not only the upper reaches of urban society that is being housed in segregated condominiums near the coastline. A few kilometres further out along the newly built ring-road, the housing project Casa Jovem was planned to become a financially accessible option for young and upwardly mobile Mozambicans between the age of 25 and 40. With prices ranging from US\$25,000 - 65,000 for individual 35-120 $\mathrm{m}^{2}$ apartments, quite a few young middle class urbanites did initially consider Casa Jovem to be a viable solution to their immediate housing needs.

Jacinta David was one of the first young middle-class residents to buy an apartment in Casa Jovem. Originally, from Xai-Xai, the capital of the Gaza region, Jacinta moved to Maputo with her parents when her father was transferred to a midlevel position within the Ministry of Agriculture. Shortly after finishing her studies at the Eduardo Mondlane University in Maputo, Jacinta got a job as a financial consultant in the USA where she stayed for three years before returning to Mozambique in 2012 determined to make a career as an economist within the state apparatus. Nielsen first met Jacinta in the spring of 2015 during a lunch break from her work at the Ministry of Finance.

"I really wanted an apartment close to work but most of the buildings in that area are completely run down. And so noisy... Also, I was looking for a place where I could hang out with people my own age who are interested in the same things as me. You know... serious people (pessoas sérios)..."

Since first moving to Maputo, Jacinta's parents had invested a considerable sum of money in real estate and were now keen on helping their daughter buying a nice apartment. It was Jacinta's mother who first read about the Casa Jovem project and contacted the Mozambican real estate company to arrange a viewing. "I liked the look of the place", Jacinta told Nielsen. "I could easily imagine myself having a future there... friends and even colleagues living nearby. Like-minded people... (laughs)". Unfortunately, though, things did not go as planned. The construction process was consistently delayed, and it was soon apparent that the apartment buildings that had been erected during the first phase of the project had a number of serious construction weaknesses causing, for example, abrupt and prolonged cuts in water and electricity. As a direct result of the problem-ridden construction process, many of the young urbanites who had initially considered buying apartments in Casa Jovem soon turned their attention to other and more viable housing possibilities in condominiums elsewhere in the city, such as the 'Intaka Community' located on Maputo's northern periphery.

The 'Intaka Community' is developed through a collaboration between the national Housing Fund (Fundo de Fomento de Habitacão FHH), and the Henan Guoji Real Estate Ltd., a Chinese construction consortium. When completed, the already impressive condominium will be the largest gated community ever built in 
Mozambique. The first phase has been concluded and 700 housing units have already been built, of which more than 300 are occupied. If the building project is ultimately realized in accordance with the initial master plan, the area will comprise 5,000 housing units and accommodate an expected population of 15,000-20,000 residents. With an average price of approximately US $\$ 25,000$ for the smallest two-room houses (40 m2) and US\$90,000 for three-room houses (60-70 m2), Intaka predominantly attracts lowerlevel state officials, whose salaries suffice for this kind of state-initiated compound but not for the expensive housing units in the luxurious condominiums near the coastline. Interestingly, one of the middle-class urbanites who were attracted to the 'Intaka Community' was Jacinta David. To be sure, it did not take long for Jacinta to realise that the initial promises of Casa Jovem would never materialise and she therefore started to look elsewhere for more stable housing.

"One of my friends, who works at $\mathrm{INCM}^{2}$ had already bought a house in Intaka. I went there one weekend and met his neighbours. It was a nice place. Quiet. And the houses looked much nicer than the apartment buildings in Casa Jovem"

Many young urbanites, such as Jacinta David, who bought a three-room house in the Intaka Community by getting a loan from her parents have since invested in relatively financially accessible housing in the 'Intaka Community'. Not only does it meet the immediate demands for secure housing in an area detached from the chaos and dysfunctional infrastructure of the inner-city; it also seems to afford a social community of like-minded and entrepreneurial young urbanites with ambitious career plans and aspirations of soon advancing within the state system.

Housing in Maputo has thus become not only the material base but, as we discuss in the next section, also a primary cultural expression of a new, capitalist and modern self-identified middle class. As with the socialist political aesthetic, allegiance is still expressed through cultural markers, comportment and the ability to surround oneself with 'like-minded', 'serious' people. However, the current configuration of attachment to values associated with middle classness is increasingly separate from the nation; the symbol of autonomy is being locked away and guarded from the chaos and disorder of the existing city by high walls and elaborate security systems. As such, urban housing has created a material base for a party-connected social group that identifies as a new, modern 'middle class', but whose practices nevertheless tend to reproduce the existing social order as well as the group's own dependence on the political elite.

\section{Alienation and Reproduction: the Middle Class Lament}

\footnotetext{
${ }^{2}$ O Instituto Nacional das Comunicações de Moçambique (Mozambique's National Institute of Communication)
} 
During the summer of 2019, Sumich was speaking to a friend, Evaristo, in a café in Sommerschield, one of the wealthiest neighbourhoods in Maputo. Evaristo was talking about the last election.

Yes, it looked like Renamo might be able to win here, they had huge rallies in Maputo and that has never happened before, crazy. Then 24 hours go by and no election results are released, and I am thinking, OK this will obviously be fraud. Then, big surprise, they announce that Frelimo has won. You know what I felt? Relief! I mean the Renamo guys have been in the bush with nothing for years. What is going to happen when they march into Sommerschield, see all these big, fancy houses and realise that they all belong to Frelimo people? The need for revenge will be strong. God knows what else will happen.

Evaristo's comments, which display both contempt for and dependence on the political order, are strikingly similar to those made by many of the privileged urbanites that we have met in Maputo. They refer to ongoing social tension, the brittleness of the current system, which they may despise, but which also sustains them and the centrality of housing to conceptions of privilege. Crucially, however, these attempts at activating a still dominant political aesthetics should not be seen as strategies tied to a nationalist ideological struggle. As one of our interlocutors put it: "we (by which she meant members of her camada social or social layer) are stuck in the ruins of a collapsed project and we do not know how to get out". Rather, a main ambition for many urbanites, who think of themselves as members of the middle class, is to secure one's personal and familial position in a social order that has long been characterized by precarity. Either from the purges of the socialist period, the dislocations of the civil war, or the constantly shifting terrain of current practise of what is popularly known as 'savage capitalism'.

Those at the other end of the spectrum of 'middle classness' need to engage with the political aesthetics of the state in a more explicit, less ironically detached manner in order for them to establish a viable and secure position from which advancement is possible. One must continue to demonstrate loyalty to the state while, at the same time, engaging in a variety of provisional aesthetic practices that focus on autonomy and security in the hopes of advancement. A prime example of this is the 'Intaka Community' on the northern periphery of the city discussed earlier. In many ways, the layout and physical aesthetics of Intaka resemble those of other gated communities and condominiums found throughout sub-Saharan Africa and the Americas (Caldeira 2001; de Boeck 2011; Murray 2015): surrounded by three-metre-high brick walls topped with an electric fence, an interior space is laid out as straight rows of identical houses interspersed with a number of public squares and playgrounds. Eventually, the Intaka Community will also have a mall with a supermarket and several small stores to cater to the needs of the area's population who wish to avoid going to the city centre for their daily shopping. 
Hence, while it could be imagined that the initial ambition with the Intaka Community was to create a privatized enclave for an assumed growing urban middle class, the developers were equally inspired by socialist ideals from Mozambique's early independence years on collective habitation and restricted privacy. Individual plots are separated only by small 40- to 50-centimetre-high cement walls or criss-crossed wooden 'Belgian' fences that reach only halfway from the house to the street. Contrary to the overall ideal of promoting further collectivism within the gated community, however, residents have begun adding additional walls in order to separate themselves from neighbours and passers-by. Some have even augmented these new walls, some of which are more than three metres high, with additional electric fences or surveillance systems to monitor activities on the sidewalk outside their plots. To the main project developer, the alterations made by the residents were a cause of continuous frustration and bewilderment. Nielsen met up with him at a new coffee shop in the city centre to discuss the situation in Intaka:

"What is going on out there? Don't they know that they are properly protected by the guards? I really can't figure out why they don't like the area as it is..."

Although the developer was frustrated about the collapse of the collective vision, residents were pushing for even more privacy. Gilda was a 32-year-old accountant who moved to Intaka in 2015. For the previous six years she had lived in a small two-room apartment in the city centre, both to be close to her workplace and also to visit her parents on a regular basis. However, when Gilda heard about the possibility of affordable houses in Intaka, she did not hesitate to contact the real estate agency. 'Living in the city centre is not great', she told Nielsen during a walk around the compound in the fall of 2016. 'The traffic situation is a mess ... And living in an apartment, there is so much noise from people in the building, who do not respect their neighbours' right to privacy'. Hence, even with the additional time she had to spend commuting back and forth to the city centre every day, it was an easy choice to move to Intaka. 'Ah! And the electricity works here'! Gilda laughed and nodded towards one of the streetlights illuminating a nearby playground. 'In the city, it's a nightmare. Did you know that the power was gone for more than eight hours last week? And in the city centre...! Imagine that!'

Gilda did appreciate the area's efficient infrastructure and relative calm in contrast to the inner city's noisy chaos, but she did not consider her current housing conditions ideal. To her and several other Intaka residents that Nielsen spoke with, a house in the walled compound was a preferred alternative primarily because it constituted an economically feasible way of moving out of a small and over-priced apartment in one of the city's many dilapidated buildings. Very few (if any!) of the residents were particularly impressed by the Mozambican real estate agent's initial praise of Intaka as 'the realization of all Mozambican citizens' desire to join the middle class'. Throughout the years, Frelimo has broken too many promises for Gilda and her peers to believe in a 
collective middle-class utopia designed in collaboration with a Chinese construction consortium, which clearly had no sense of Mozambican housing aesthetics. 'There is no real middle class in Mozambique', Gilda told Nielsen as he was leaving the condominium. 'Here, the rich make a living from the sweat of the poor'. Hence, rather than attempting to fake inclusion in a community that would never be realized, residents in Intaka prioritized the privacy of their home by further improving the physical separation of individual plots. To Gilda, her house in Intaka was merely a first step towards eventually buying a house in one of the city's luxurious neighbourhoods. Only by doing so would she be able to achieve the status and security necessary to avoid the uncertainties and everyday hassle that most Mozambicans have to cope with, even if she remained uncertain about how to concretely achieve this goal. In order to make such a move, Gilda had provisionally appropriated the aesthetics of the state but, in doing so, she was already looking forward to a future moment when she could leave it behind and assert her own independence. 'The state is like a wealthy parent', Gilda said with a laugh. 'You need their money in order to leave them'.

Ironically, the ability to bypass the state can be considerably more difficult for those closer to the centre of power. In such cases, housing can symbolise one's attempts to escape the social order and carve an autonomous space out for oneself but, at the same time, the practices necessary to attempt this tend to have the overall effect of reproducing relationships of domination. An apt illustration occurred on Sumich's visit with a friend, João, to his quinta (country house or estate). João's family was wellestablished during the colonial period and had been active with Frelimo since the liberation struggle. The quinta was acquired by João's father during the privatization period. As they strolled across the spacious, well-tended grounds, João absently issued orders to deferential groundskeepers and outlined his plan to leave his government post and start businesses on his various properties. While João's property is part of a material strategy to consolidate himself, it is also a symbolic expression of an ideal of autonomy that is deeply interlinked with his position of status and moral worth, the cultural markers of privilege in Maputo. It is also, we might add, a reflection of the contradictions at the core of the political aesthetics of middle classness in Mozambique. During the privatization period, João's father failed to give the party its cut of the properties and enterprises he acquired, and the family fell into disgrace. João took a low-ranking position at a ministry to try and make amends. The reason Sumich and João had driven to the quinta that day had been so that the latter could collect the monthly tribute for his boss from the 'fees' extracted by the traffic police that lined the route. As such, João's quinta, like other houses of the privileged, manifests the two registers of the political aesthetics of middle classness in Mozambique, namely the desire and drive towards autonomy even while it bolsters dependence on the powerful.

\section{Conclusion}

While housing has become a primary vehicle for privileged urbanites in Maputo to consolidate their positions, the decreasing availability of land, the growing number of 
contestations over property rights and the overall economic instability are fundamentally challenging its future viability to function as such. This precariousness has become blindingly obvious during the ongoing financial crisis, which began in 2014 (Hanlon 2016). After wild borrowing based on dreams of mineral and natural gas fuelled abundance, the global price collapse for natural resources has left the government on the brink of default, with a long list of legally dubious debts it had hitherto hidden from both creditors and its population. Amid rising inflation, disputed elections, periodic political violence and sharply depreciating salaries, housing prices have begun to fall, hinting that the bubble may finally be bursting and putting the material basis of the self-proclaimed middle class at risk. Despite the severity of the situation, though, the crisis has not yet caused our interlocutors to alter their strategies; if anything, they are intensifying their efforts. Feverish housing construction and speculative land transactions continue unabated, although there are growing doubts as to whether the seemingly endless number of new construction projects for the privileged segments of the Mozambican society will ever be completed. Indeed, despite the gloomy projections for an ever more tenuous economic future, a main driver of middle classness in Maputo continues to be the search for land and the consolidation of secure spaces, such as those found in hubs spread throughout the city for working, shopping, dining, drinking, and entertainment.

In many ways, this tenuous situation illustrates the entrapment of a political aesthetic that structures what is considered as 'sensible' for those trying to establish a viable position in the city on the basis of assumed middle-class autonomy. Ever more resources are poured into housing at the same time as the underlying economic and political system teeters on the verge of the abyss. As Ranciére tells us, political aesthetics refers to a 'recasting of the distribution of the sensible, a reconfiguration of the given perceptual forms' (2004:63). The manifestation and enactment of a political aesthetics is therefore not necessarily a revolutionary overturning of a political arrangement but, rather, a gradual and sometimes almost imperceptible realisation that an existing social or cultural configuration of meaning carries within it the potentials for different kinds of positions and forms of identification. In this regard, political aesthetics suggests that different registers of meaning can be activated simultaneously, such as the double activation of 'middle classness' as distanciation from the ideology of a collapsed post-socialist rule and the vehicle for the reproduction of the latter. This may, Ranciére argue, potentially allow for new openings, subject positions and spaces of identification, to be inscribed in the social fabric even when there seems to be no manifest contestation of existing socio-political rights and privileges.

In Maputo, then, differently positioned urbanites who engage with diverging notions of 'middle classness' both repudiate and are trapped by a defunct ideological project. In this regard, housing has become the embodiment of a particular political aesthetic on two levels. For those closer to the centre of power, it is through the house that a wider symbolic vocabulary is articulated that figures social personhood as interconnected with the legitimacy of privilege. The house then becomes the emblem of 
modern citizenship and autonomy, even while the ability to procure it reproduces relationships of domination For of somewhat lesser privilege it is the exterior aesthetics of the house, which, more than anything, symbolically reverberates with possibilities for upward social mobility and a deeper attachment to already sedimented structures of economic influence and political authority. There is, then, a shared basis in the political aesthetics of urban housing but with varying effects. Whereas for the former, the house is what allows for an intensified emphasis on social personhood as a singular and partially detached entity, for the latter, the house is the main medium by which to symbolically eradicate differences between oneself and the state in order to, eventually, also transcend this univocity. Indeed, as Gilda reminded us above, that is the only viable strategy for obtaining individual autonomy. Significantly, for both relatively privileged groups, the overall effect is the reproduction of an increasingly unstable political order that our interlocutors view as corrupt and morally bankrupt, but one to which, for them, there is no exteriority.

Our research suggests, then, that the configuration of a privileged social group, such as the middle class in Mozambique - or anywhere else for that matter - is articulated through the political aesthetic that its members are invariably embedded in but which they do not necessarily support. The rhetoric of the middle class issuing forth from institutions like the World Bank, the African Development Bank and the IMF shows a striking resemblance to previous discourses concerning modernization theory (Kalb 2014). Once again, citizens can be reshaped into 'rational', autonomous, governable subjects. This is a potentially attractive vision for some and bases itself, at least in Maputo, on similarities, superficial or otherwise, in the lifestyle and aspirations of the particular subject group. However, any sort of social category, such as a 'middle class', grows out of a particular configuration of domination and inequality. Instead of acting as an agent of social transformation, a middle class, as our evidence suggests, can be instrumental in reproducing a social order that even they despise.

Acknowledgements

Will be added if accepted for publication

\section{Bibliography}

Andersen, J.E. (2012). Home Space: Socio-Economic Study (Research Programme 'Home Space in African Cities' funded by the Danish Research Council for Innovation 2009-2011). Copenhagen: The Royal Danish Academy of Fine Arts, School of Architecture, Department of Human Settlements.

Buire, C. (2017). "New City, New Citizens?: A Lefebvrian Exploration of State-Led Housing and Political Identities in Luanda, Angola." Transformation, 93, 13 - 40

Buur, L. (2010). “Xiconhoca: Mozambique's Ubiquitous Post-Independence Traitor.” In Sharika Thiranagama \& Tobias Kelly (eds.), Traitors: Suspicion, Intimacy and 
the Ethics of State-Building, 24-47. Philadelphia, PA: University of Pennsylvania Press.

Caldeira, T. (2001). City of Walls, Crime, Segregation, and Citizenship in São Paulo. Berkeley, University of California Press.

Castel-Branco, C; C. Cramer, C; \& D. Hailu. (2001). "Privatisation and Economic Strategy in Mozambique.” Discussion Paper No. 2001/64. London: WIDER, United Nations University.

Costa, A. B. d. (Forthcoming). "Maputo, Urban Mobility and Sociocultural and Spatial Transformation Processes." Journal of Contemporary African Studies.

---. (n.d.). Condominiums and exclusive neighbourhoods in Angola and Mozambique (Unpublished manuscript). ISCTE--IUL.

Cruz e Silva, T. (2001). Protestant Churches and the Formation of Political Consciousness in Southern Mozambique (1930-1974). Basel: P. Schlettwein Publishing.

Dalakoglou, D. 2010. "Migrating-Remitting-'Building'-Dwelling: House-Making as 'Proxy' Presence in Postsocialist Albania." Journal of the Royal Anthropological Institute, 16, 761-777

De Boeck, F. (2011). "Inhabiting Ocular Ground: Kinshasa's Future in the Light of Congo's Spectral Urban Politics." Cultural Anthropology 26(2): 263-286.

Dinerman, A. (2006). Revolution, Counter-Revolution and Revisionism in Postcolonial Africa: The Case of Mozambique, 1975-1994. London \& New York, NY: Routledge.

FIAN International Secretariat (2010). Land Grabbing in Kenya and Mozambique. A Report on Two Research Missions - and a Human Rights Analysis of Land Grabbing. Heidelberg,

Ferguson, J. (1998). "Transnational topographies of power, Beyond 'The State' and 'Civil Society' in the study of African politics." In: H. S. Marcussen and S. Arnfred, (Eds.): Concepts and Metaphors, Ideologies, Narratives and Myths in Development Discourse. Roskilde, Roskilde University. International Development Studies Occasional Paper no. 19: pp. 45-71.

Gastrow, C. (2017). “Aesthetic Dissent: Urban Redevelopment and Political Belonging in Luanda, Angola." Antipode. 49 (2): 377 - 396

GlobalPost (online) (2010) Africa's Middle Class: Striving to Develop a Continent.

Hanlon, J. (2016). "Following the Donor-Designed Path to Mozambique’s US\$2.2 Billion Secret Debt Deal." Third World Quarterly: 1-18.

Heiman, R; M. Liechty; \& C. Freeman. (2012). "Introduction: Charting an Anthropology of the Middle Classes." In Rachel Heiman, Mark Liechty \& Carla Freeman (eds.), 3-29. The Global Middle Class: Theorizing Through Ethnography. Santa Fe, NM: SAR Press.

Jenkins, P. (1998). National and international shelter policy initiatives in Mozambique: housing the urban poor at the periphery. Centre for Environment and Human Settlements, School of Planning and Housing. Edinburgh, Heriot Watt University. 
---. (2001). Emerging urban residential land markets in post-Socialist Mozambique:

The impact on the poor and alternatives to improve land access and urban development. Edinburgh, ECA school of planning and housing. Edinburgh

College of Art / Heriot-Watt University.

---. (2013). Urbanization, Urbanism and Urbanity in an African City. New York, Palgrave Macmillan.

Kalb, D. (2014). "Class: The Urban Commons and the Empty Sign of 'the Middle Class' in the Twenty-First Century." In Donald Nonini (ed.), 157-176. A Companion to Urban Anthropology. New York, NY: John Wiley \& Sons.

Kipnis, A. "Neoliberalism Reified: Suzhi Discourse and Tropes of Neoliberalism in the People's Republic of China." Journal of the Royal Anthropological Institute, 13:2, (2007): 384-400, 385.

Lentz, C. (2015). "Elites or Middle Classes? Lessons from Transnational Research for the Study of Social Stratification in Africa". Mainz, Germany, Institut für Ethnologie und Afrikastudien, Johannes Gutenberg-Universität.

Lopes, C. (2015). "Emerging Africa, its Middle Class and New Development Challenges." The Hague, Netherlands, Economic Commission for Africa, United Nations.

McAuslan, P. (2013). Land Law Reform in Eastern Africa: Traditional or transformative? A Critical Review of 50 Years of Land Law Reform in Eastern Africa. New York, NY, Routledge.

Mercer, C. (2014). "Middle Class Construction: Domestic Architecture, Aesthetics and Anxieties in Tanzania." Journal of Modern African Studies, 52, 2, 227-250.

Melber, H. (2016). "The African Middle Class(es) - in the Middle of What?" Review of African Political Economy: 1-13.

Melly, C. (2017). Bottleneck: Moving, Building and Belonging in an African City. Chicago and London: University of Chicago Press.

Morange, M., F. Folio, et al. (2012). "The Spread of a Transnational Model: 'Gated Communities' in Three Southern African Cities (Cape Town, Maputo and Windhoek)." International Journal of Urban and Regional Research 36(5): 890914.

Mubila, Maurice et al. (2011). The Middle of the Pyramid: Dynamics of the Middle Class in Africa. African Development Bank: Market Brief April $20^{\text {th }}$.

Murray, M. J. (2015). "Waterfall City (Johannesburg): Privatized Urbanism in Extremis." Environment and Planning A 47(3): 503-520.

Ncube, M. and A. Shimeles (2013). The Making of the Middle Class in Africa: Evidence from DHS Data. IZA DP no. 7352. Bonn, Germany, Institute for the Study of Labor.

Negrão, J. (2004). Mercado de Terras Urbanas em Mocambique. Maputo, Cruzeiro do Sul.

Nielsen, M. (2014). "The Negativity of Times. Collapsed Futures in Maputo, Mozambique." Social Anthropology 22(2): 213-226.

---. (2016). Into Architecture. House-building and acentered personhood in Maputo, Mozambique in: M. Bille and T. F. Sørensen, (Eds.): Elements of Architecture. Assembling Archaeology, Atmosphere and the Performance of Building Spaces. London \& New York, Routledge: pp. 273-286. 
---. (2017). "Ideological Twinning : Socialist aesthetics and political meetings in Maputo, Mozambique." Journal of the Royal Anthropological Institute 23(S1): 139-153.

---. (2020 (forthcoming)). "Rooftop Autophagy. Vertical Monadism in Maputo, Mozambique." Urban Forum.

Nielsen, M. and P. Jenkins (2019 (Forthcoming)). "Insurgent aspirations?: Weak Middle Class Utopias in Maputo, Mozambique." Critical African Studies.

Nunes Silva, C., (Ed.) (2015). Urban Planning in Lusophone African Countries. Farnham, Ashgate.

Paasche, T. F. and J. D. Sidaway (2010). "Transecting security and space in Maputo." Environment and Planning A 42: 155-1576.

Paulo, Margarida; C. Rosário \& I. Tvedten. (2007). 'Xiculungo': Social relations of urban poverty in Maputo, Mozambique. Published Report. Bergen: CMI.

Pinsky, B. (1982). The Urban Problematic in Mozambique: Initial Post-Independence Responses, 1975-1980. Major Report No. 21. Centre for Urban and Community Studies. University of Toronto.

Pitcher, A. (2002). Transforming Mozambique: The Politics of Privatization, 1975 2000. New York, NY \& Cambridge: Cambridge University Press.

---. (2006). Forgetting from Above and Memory from Below: Strategies of Legitimation in Postsocialist Mozambique. Africa 76(1): 88-112.

-_- (2012). Party Politics and Economic Reform in Africa's Democracies. New York: Cambridge University Press

Pow, C-P. (2009). "Neoliberalism and the Aestheticization of New Middle-Class Landscapes." Antipode, 41 (2), 371-390

Quembo, C. (2009). The Rise of Condominios Fechados in Costa do Sol, Maputo. Security, Urban Dynamics and Segregation in: C. Benit-Gbaffou, F. Seyi and E. Peyroux (Eds.): Sécurisation des Quartiers et Gouvernance Locale. Enjeux et Défis pour les Villes Africaines pp.

---. (n.d.). How Perceptions Matter: Urban Mobility and Settlement in Maputo and Matola (Mozambique) Since Independence (Unpublished manuscript). Maputo.

Rancière, J. (2004). The Politics of Aesthetics. London, Continuum.

Roque, S., M. Mucavele, et al. (2016). "Subúrbios and Cityness: Exploring Imbrications and Urbanity in Maputo, Mozambique." Journal of Southern African Studies 42(4): 643-658.

Saul, J. S., (Ed.) (1985). A Difficult Road: The Transition to Socialism in Mozambique. New York, NY, Monthly Review Press.

Schubert, Jon (2016)." Emerging Middle-Class Political Subjectivities in Post-War Angola." In Henning Melber (ed.), Examining the African middle class(es).

London: Zed Books. 147-158.

Soares de Oliveira, R. (2015). Magnificent and Beggar Land: Angola Since the Civil War. London: Hurst \& Company.

Southall, R. 2016. The New Black Middle Class in South Africa, Johannesburg and New York, NY: James Currey.

Spronk, R. (2012). Ambiguous Pleasures: Sexuality and Middle Class Self-Perceptions in Nairobi. Oxford, Berghahn. 
Sumich, J. (2016, first published online 2015) "The Uncertainty of Prosperity:

Dependence and the Politics of Middle Class Privilege in Maputo." Ethnos, 81

(5), 821-841.

---. 2018, The Middle Class in Mozambique: The State and the Politics of

Transformation in Southern Africa. Cambridge: Cambridge University Press.

Swedesurvey (1999). Comparative Study of Real and Documented Land Use and Land Occupation and Legal Support to Urban Land Management. First Volume:

Evaluation of the Existing Situation. Final Report. Maputo, Direcção de Construção e Urbanização.

Vieira, Sergio (1977). The New Man is a Process. A Speech by Sergio Vieira, Member of the Central Committee of Frelimo to the Second Conference of the Ministry and Culture, held in December.

Wise, T. A. (2015). "The Great Land Giveaway in Mozambique." Retrieved 7 April, 2015, from http://farmlandgrab.org/post/print/24666. 